\title{
ANALISIS MASLAHAH TERHADAP PERMA NOMOR 3 TAHUN 2017 TENTANG PEDOMAN MENGADILI PERKARA PEREMPUAN BERHADAPAN DENGAN HUKUM
}

\begin{abstract}
Silmi Mursidah
Brontosaren 6/2 Kenongorejo Pilangkenceng Madiun. E-mail: silmimursyidah09@gmail.com

Abstract: This Supreme Court regulation was formed because there is still widespread discrimination and gender stereotypes in the courts in Indonesia. This regulation is a maslahah hajiyah because this benefit is needed by humans, especially women who are faced the law for the convenience of their lives. If this regulation is not implemented, it will cause difficulties and negative impacts on women, both psychologically and physically. However, these difficulties do not damage the order of buman life. The issuance of the Supreme Court regulation, it is expected that gender stereotypes will no longer occur in examinations in courts that can have a negative impact on women dealing with the law, both psychologically and physically, and the issuance of decisions that are gender biased. Supreme Court Rule Number 3 of 2017 concerning Guidelines for Judging the Case of Women Facing the Law, hoped that it can become a standard for judges and all judicial apparatus, in the process of examination in the courts in handling cases involving women, both as perpetrators, victims, witnesses and parties, so that the goal of eliminating all potential discrimination against women facing the law can be achieved.
\end{abstract}

Keywords: maslahah and women facing the law

Abstrak: Peraturan Mahkamah Agung ini dibentuk karena masih marak terjadi diskriminasi dan stereotip gender dalam peradilan di Indonesia. Peraturan ini merupakan maslabah hajiyah karena kemaslahatan ini yang dibutuhkan manusia khususnya perempuan berhadapan dengan hukum untuk kemudahan hidupnya. Jika peraturan ini tidak dilaksanakan, maka akan menimbulkan kesulitan dan dampak negatif bagi diri perempuan, baik psikis maupun fisik. Namun, kesulitan tersebut tidak merusak tatanan kehidupan manusia. Dengan dikeluarkannya peraturan Mahkamah Agung ini diharapkan tidak lagi terjadi stereotip gender dalam pemeriksaan di pengadilan yang dapat berdampak negatif terhadap perempuan berhadapan dengan hukum, baik psikis maupun fisik, serta dikeluarkannya putusan yang bias gender. Peraturaan Mahkamah Agung Nomor 3 Tahun 2017 tentang Pedoman Mengadili Perkara Perempuan Berhadapan Dengan Hukum, diharapkan dapat menjadi standar bagi para hakim dan segenap aparatur peradilan, dalam proses pemeriksaan di pengadilan

AL-HUKAMA

The Indonesian Journal of Islamic Family Law Volume 08, Nomor 01, Juni 2018; ISSN:2089-7480 
dalam menangani perkara yang melibatkan perempuan, baik sebagai pelaku, korban, saksi, dan para pihak, sehingga tujuan penghapusan segala potensi diskriminasi terhadap perempuan yang berhadapan dengan hukum dapat tercapai.

Kata Kunci: maslahah dan perempuan berhadapan dengan hukum

\section{Pendahuluan}

Salah satu prinsip pokok ajaran Islam adalah prinsip persamaan antar manusia baik laki-laki dan perempuan, maupun antar suku, bangsa, dan keturunan. Hal ini diisyaratkan dalam QS. al-Hujurat: 13:

Hai manusia sesunggubnya kami menciptakan kamu dari seorang lakilaki dan seorang perempuan dan menjadikan kamu berbangsa-bangsa dan bersuku-suku supaya kamu saling mengenal. Sesunggubnya orang yang paling mulia diantara kamu adalah orang yang paling bertakwa diantara kamu.1

Ayat tersebut memberikan gambaran tentang persamaan antara laki-laki dan perempuan baik dalam hal ibadah (dimensi spiritual) maupun dalam aktivitas sosial (urusan karier profesional). Ayat ini juga mempertegas misi pokok al-Quran diturunkan, yaitu untuk membebaskan manusia dari berbagai bentuk diskriminasi dan penindasan, termasuk diskriminasi seksual, warna kulit, etnis dan ikatan-ikatan primordial lainnya. Namun demikian sekalipun secara teoretis al-Qur'an mengandung prinsip kesetaraan antara laki-laki dan perempuan, namun ternyata dalam tatanan implementasi seringkali prinsip-prinsip tersebut terabaikan.2

Ketidakadilan relasi antara laki-laki dan perempuan inilah yang sering disebut dengan ketidakadilan gender. Gender adalah jenis kelamin bentukan yang dikonstruksi oleh budaya dan adat istiadat, seperti laki-laki kuat, berani, cerdas, menguasai, sedangkan perempuan itu lemah, penakut, kurang cerdas (bodoh), dikuasai. Isu gender menguat ketika disadari, bahwa perbedaan gender antara manusia laki-laki dan perempuan telah melahirkan ketidakadilan dalam berbagai bentuk seperti marginalisasi atau pemiskinan

1 Kementrian Agama RI, Al Quran dan Tafsimya, (Jakarta: Widya Cahaya, 2011), 516.

2 Sarifa Suhra, "Kesetaraan Gender dan Implikasinya dalam Hukum Islam", Jurnal al-Ulum, No. 2 Vol. 13 (Desember 2013), 374. 
ekonomi, anggapan tidak penting dalam urusan politik, dan pencitraan yang negatif bagi perempuan. 3

Ketidakadilan gender terhadap perempuan tersebut terjadi secara sistematis dan terstruktur sehingga menjadikan pihak yang tertindas tidak sadar dan menjadi kebiasaan. Tidak hanya kaum lakilaki saja yang ikut mentradisikan ketidakadilan gender, perempuan juga ikut mengabadikan perilaku tersebut karena mereka berasumsi, bahwa kenyataan tersebut sudah tidak perlu untuk dikoreksi dan dievaluasi, dan dianggap kodrat ilahi yang diberikan kepada makhluknya di bumi.4

Di Indonesia sendiri untuk menghindari segala tindakan diskriminasi terhadap perempuan telah dibentuk beberapa peraturan perundang-undangan, diantaranya Undang-Undang Nomor 12 Tahun 2005 tentang pengesahan Covenant on Civil and Political Rights (Kovenan Internasional tentang Hak-Hak Sipil dan Politik) yang menegaskan bahwa semua orang adalah sama di hadapan hukum dan peraturan perundang-undangan melarang diskriminasi serta menjamin perlindungan yang setara bagi semua orang dari diskriminasi berdasarkan alasan apapun, termasuk jenis kelamin atau gender. Serta Undang-Undang Nomor 7 Tahun 1984 tentang pengesahan konvensi mengenai Penghapusan Segala Bentuk Diskriminasi Terhadap Wanita (Convention on The Elimination of All Forms of Discrimination Against Women). Namun meskipun sudah dibentuk undang-undang diatas, perempuan masih sering menghadapi rintangan berganda dalam meraih pemenuhan haknya yang disebabkan oleh diskriminasi dan pandangan stereotip negatif berdasarkan jenis kelamin dan gender. Perlakuan diskriminatif dan stereotip gender terhadap perempuan dalam sistem peradilan berbanding lurus dengan aksesibilitas perempuan untuk mendapatkan keadilan. Semakin perempuan mengalami diskriminasi

3 Ibid, 375.

4 Husein Muhammad, Fiqih Perempuan: Refleksi Kiai atas Wacana Agama dan Gender, (Yogyakarta: LkiS, 2009), 8. 
dan/atau stereotip negatif maka akan semakin terbatas akses perempuan terhadap keadilan. 5

Melihat berbagai kondisi tersebut, Mahkamah Agung sebagai lembaga pengadilan tertinggi berinisiatif untuk mengambil langkah guna secara bertahap memastikan tidak ada diskriminasi berdasarkan gender dalam praktik peradilan di Indonesia. Salah satu langkah kongkrit Mahkahamah Agung adalah dengan mengeluarkan Peraturan Mahkamah Agung Republik Indonesia Nomor 3 Tahun 2017 tentang Pedoman Mengadili Perkara Perempuan Berhadapan Dengan Hukum. Peraturan ini dikeluarkan untuk menghindari terjadinya diskriminasi ketika pemeriksaan di pengadilan berlangsung dan munculnya putusan yang bias dan pro gender. Misalnya dalam perkara pembagian harta warisan, hukum adat, nusyuz dalam perceraian, hak perempuan pasca perceraian, hak asuh anak, KDRT, dan sebagainya.6

Sementara itu peran serta perempuan semakin dibutuhkan dalam berbagai lini kehidupan termasuk pada bidang hukum. Untuk itulah tulisan ini akan membahas lebih jauh tentang "Analisis Maslabah terhadap Peraturan Mahkamah Agung Nomor 3 Tahun 2017 Tentang Pedoman Mengadili Perkara Perempuan Berhadapan Dengan Hukum". Penelitian ini dibahas oleh penulis sebagai bentuk kepedulian menanggapi isu gender.

Kajian tentang isu perempuan menggunakan perspektif Islam sudah banyak dilakukan, misalnya Siti Aminah yang berjudul "Dekonstruksi Fikih Maskulin: Studi Kritis atas Kasus Amina Wadud sebagai Imam Shalat Jum'at di Gereja Italian Unity, Morgantown, West Virginia, Amerika Serikat" pada tahun 2006. Penelitian ini mengungkap bagaimana pembahasan tentang imam wanita dari

5Pokja Perempuan dan Anak Mahkamah Agung Republik Indonesiadan MaPPI FHUI, Pedoman Mengadili Perkara Perempuan Berhadapan Dengan Hukum, (Jakarta: AIPJ, 2018), 10.

6Rahmat Arijaya, “Inilah Materi Pelatihan PERMA Nomor 3 Tahun 2017”, dalam https://badilag.mahkamahagung.go.id/seputar-ditjen-badilag/seputar-ditjenbadilag/inilah-materi-pelatihan-perma-nomor-3-tahun-2017, diakses pada 18 november 2017. 
pandangan fikih.7 Kajian lainnya misalnya yang dilakukan oleh Anik Mahmudah yang berjudul "Produktifitas Perempuan: Studi Analisis Produktivitas Perempuan dalam Konsep Islam" pada tahun 2004. Penelitian ini membahas tentang Produktifitas perempuan secara general dalam konsep Islam.8 Sejauh penelusuran penulis belum ada kajian yang melihat sisi kemaslahatan Peraturan Mahkamah Agung Republik Indonesia Nomor 3 Tahun 2017 tentang Pedoman Mengadili Perkara Perempuan Berhadapan Dengan Hukum.

\section{Konsep Maslahah dalam Hukum Islam}

Dari segi bahasa maslabah berasal dari kata salaha yang secara arti kata berarti baik lawan dari kata buruk atau rusak. Ia adalah mashdar dari saluba yaitu yang berarti kebaikan atau terlepas dari kesulitan.9 Dan juga bisa dikatakan maslahah itu merupakan bentuk tunggal dari masalih. Pengarang kamus Lisan al-'Arab seperti yang dikutip Rachmat Syafei menjelaskan dua arti, yaitu maslabah yang berarti al salah dan maslahah yang berarti bentuk tunggal dari al-masalih. Semuanya mengandung arti adanya manfaat baik secara asal maupun melalui proses, seperti menghasilkan kenikmatan dan faedah, ataupun pencegahan dan penjagaan seperti menjauhi kemudharatan. Semua itu bisa disebut maslahah.10

Dalam bahasa arab pengertian maslahah berarti "perbuatanperbuatan yang mendorong kepada kebaikan manusia", artinya bahwa segala sesuatu yang bermanfaat bagi manusia, baik dalam arti menarik atau menghasilkan, seperti menghasilkan keuntungan atau kesenangan atau dalam arti menolak atau menghindarkan seperti menolak kemudharatan atau kerusakan. Jadi setiap yang mengandung dua sisi, yaitu menarik atau mendatangkan kemaslahatan dan menolak atau menghindarkan kemudharatan.11

7 Siti Aminah, "Dekonstruksi Fikih Maskulin: Studi Kritis atas Kasus Amina Wadud sebagai Imam Shalat Jum'at di Gereja Italian Unity, Morgantown, West Virginia, Amerika Serikat" (Skripsi- - UIN Sunan Ampel, Surabaya, 2006).

8 Anik Mahmudah, "Produktifitas Perempuan: Studi Analisis Produktifitas Perempuan dalam Konsep Islam” (Tesis- - UIN Sunan Ampel, Surabaya, 2004). 9A. Warson Munawir, Kamus Al Munawir, (Surabaya: Pustaka Progresif, 1997), 788-789.

10Rachmat Syafei, Ilmu Ushul Fiqih, (Bandung: Pustaka Setia, 1998), 7. 11Amir Syarifudin, Ushul Fiqih,Jilid 2, (Jakarta: Kencana, 2008), 366. 
Sementara itu Al-Ghazali mengemukakan bahwa menurut asalnya maslabah itu mendatangkan manfaat dan menjauhkan dari mudharat dengan tujuan maslahah yaitu menjaga agama, jiwa, akal, keturunan, dan harta. Al-Syatibi, sebagaimana dikutip oleh Amir Syarifudin dalam bukunya Ushul Fiqih Jilid 2 mengartikan maslahah dari dua pandangan, yaitu dari segi terjadinya maslahah dalam kenyataannya dan dari segi tergantungnya tuntunan syara' kepada maslahah.

1. Dari segi terjadinya maslahah dalam kenyataannya, berarti: sesuatu yang kembali kepada tegaknya kehidupan manusia, sempurna hidupnya, tercapai apa yang dikehendaki oleh sifat syahwati dan aklinya secara mutlak.

2. Dari segi tergantungnya tuntunan syara' kepada maslahah, yaitu kemaslahatan yang merupakan tujuan dari penetapan hukum syara'. Untuk menghasilkannya Allah menuntut manusia untuk berbuat sesuatu.12

Al-Thufi, sebagaimana dikutip oleh Yusuf Al-Hamid al-'Alim dalam bukunya al-Maqasid al-ammah li al-Syari'ati al-Islamiyyah yang telah dikutip oleh Amir Syarifudin mendefinisikan maslahah sebagai ungkapan dari sebab yang membawa kepada tujuan syara' dalam bentuk ibadat atau adat. Definisi dari Al Thufi ini bersesuaian dengan definisi dari Al Ghazali yang memandang maslabah dalam artian syara' sebagai sesuatu yang dapat membawa kepada tujuan syara'.13

Dari definisi-definisi tersebut, tampak yang menjadi tolak ukur maslahah adalah tujuan-tujuan syara' atau berdasarkan ketetapan syara'. Kesimpulannya, maslahah dapat diartikan dari dua sisi, yaitu segi bahasa dan dari segi hukum atau syara'. Dalam pengertian bahasa merujuk pada tujuan pemenuhan kebutuhan manusia dan karenanya mengandung pengertian untuk mengikuti syahwat atau hawa nafsu. Sedangkan dalam arti syara' yang menjadi ukuran dan rujukannya adalah memelihara jiwa, akal, agama, keturunan, dan harta benda tanpa melepaskan tujuan pemenuhan kebutuhan

12Ibid.

13Amir Syarifudin..., 368. 
manusia, yaitu mendapatkan kesenangan dan menghindarkan ketidaksenangan.14

Ayat-ayat al Quran yang menerangkan tentang pensyariatan hukum Islam dengan kemaslahatan terdapat pada beberapa ayat dalam al Quran, diantaranya terdapat pada QS. Yunus:57-58:

Hai manusia sesunggubnya telah datang kepadamu pelajaran dari Tubanmu dan penyembub bagi penyakit-penyakit (yang berada) dalam dada dan petunjuk serta rabmat bagi orang-orang yang beriman."

"Katakanlah Dengan karunia Allah dan rahmat-Nya, hendaklah dengan itu mereka bergembira, karunia Allah dan rahmat-Nya itu lebih baik dari apa yang mereka kumpulkan.15

Firman Allah tersebut menerapkan bahwa, seberapapun sulitnya jalan yang akan ditempuh oleh hamba-Nya pasti akan dapat diselesaikan. Sebab Allah telah memberikan pedoman yaitu al Quran.

Dari segi kekuatannya sebagai hujjah dalam menetapkan hukum ada tiga macam, yaitu:

1. Al-Maslahah ad-Daruriyah

Al-Maslabab ad-Daruriyah adalah kemaslahatan yang keberadaannya sangat dibutuhkan oleh kehidupan manusia. Artinya, kehidupan manusia tidak punya arti apa-apa bila salah satu prinsip yang lima tidak ada. Lima kemaslahatan ini, yaitu memelihara agama, jiwa, akal, keturunan, dan harta benda.16

Memeluk suatu agama merupakan fitrah dan naluri insani yang tidak bisa diingkari dan sangat dibutuhkan umat manusia. Untuk kebutuhan tersebut, Allah mensyariatkan agama yang wajib dipelihara setiap orang, baik yang berkaitan dengan akidah, ibadah, maupun muamalah. Hak hidup juga merupakan hak paling asasi bagi setiap manusia. Dalam kaitan ini, untuk kemaslahatan, keselamatan jiwa dan kehidupan manusia, Allah mensyariatkan berbagai hukum yang terkait dengan itu, seperti qisas, kesempatan mempergunakan hasil sumber alam untuk

14Ibid, 370 .

15Kementerian Agama RI, Al Quran dan Terjemahnya.., 225.

16Amir Syarifudin,...371 
dikonsumsi manusia, hukum perkawinan untuk melanjutkan generasi manusia, dan berbagai hukum lainnya.17

Akal merupakan sasaran yang menentukan bagi seseorang dalam menjalani hidup dan kehidupannya. Oleh karena itu, Allah menjadikan pemeliharaan akal sebagai suatu yang pokok. Untuk itu Allah melarang minum minuman keras, karena minuman itu bisa merusak akal manusia.18

Berketurunan juga merupakan masalah pokok bagi manusia dalam rangka kelangsungan manusia di bumi. Untuk memelihara dan melanjutkan keturunan tersebut Allah mensyariatkan menikah dengan segala hak dan kewajiban yang ditimbulkannya.19

Terakhir, manusia tidak dapat hidup tanpa harta. Oleh sebab itu, harta merupakan sesuatu yang daruri (pokok) dalam kehidupan manusia. Untuk mendapatkannya, Allah mensyariatkan beberapa ketentuan untuk melindunginya yaitu hukuman bagi pencurian.20

2. Al-Maslahab al-Hajizah

Al-Maslabab al-Hajiyah adalah kemaslahatan yang dibutuhkan manusia untuk kemudahan hidupnya dan menghilangkan kesempitan. Apabila tidak ada, maka tidak sampai menyebabkan rusaknya tatanan kehidupan, seperti dalam maslahah daruri, tetapi akan menimbulkan kesempitan dan kesulitan.21

Contoh Al-Maslabah al-Hajizab ialah terdapatnya ketentuan tentang keringanan dalam ibadah, seperti rukhsab shalat dan puasa bagi yang sakit atau sedang bepergian. Dalam kehidupan sehari-hari dibolehkan berburu binatang, menikmati makanan, minuman, pakaian, tempat tinggal, dan kendaraan yang baik yang didapat dengan cara halal. Demikian juga ketentuan syariat yang membolehkan seseorang melakukan utang piutang dan

17Ibid, 115.

18 Ibid, 115.

19Ibid, 115.

20Ibid, 115.

21Wahbah Az Zuhaili, Ushul Fiqih Al Islami, Juz II, (Beirut: Darul Fikri, 1986), 1022. 
jual beli dengan cara panjar. Semua aturan-aturan tersebut tidaklah menjadi kebutuhan primer manusia, tetapi bersifat sekunder. Artinya jika aturan tersebut tidak disyariatkan tatanan hidup manusia tidak sampai rusak, tetapi mereka akan mengalami kesulitan dalam mewujudkannya.22

3. Al-Maslabah al-Tabsiniyah

Al-Maslabah al-Tabsiniyah adalah maslabah yang mana kebutuhan hidup manusia kepadanya tidak sampai tingkat daruri, juga tidak sampai tingkat baji. Namun kebutuhan tersebut perlu dipenuhi dalam rangka memberi kesempurnaan dan keindahan bagi manusia.23

Jika Al-Maslahah al-Tabsiniyah tidak terpenuhi, maka manusia tidak sampai mengalami kesulitan memelihara kelima unsur pokoknya, tetapi mereka dipandang menyalahi nilai-nilai kepatutan dan tidak mencapai taraf "hidup bermartabat".24

Contoh Al-Maslabah al-Tabsiniyah dalam ibadah adalah adanya syariat menghilangkan najis, bersuci, menutup aurat, mendekatkan diri kepada Allah dengan bersedekah dan melaksanakan perbuatan-perbuatan sunnah lainnya. Sedangkan contoh dalam kehidupan sehari-hari ialah mengikuti sopan santun dalam makan dan minum, menghindarkan diri dari sikap foya-foya dan boros, serta melakukan hal-hal yang dipandang kotor dan keji. Sedangkan contoh dalam bidang muamalah adalah adanya larangan melakukan transaksi dagang barangbarang yang najis dan diharamkan dan larangan membunuh anak-anak dan wanita dalam peperangan. Semua itu tidak termasuk dalam kategori daruriyah maupun bajiyat dalam memelihara unsur pokok yang telah disebutkan. Tetapi karena adanya syariat yang mengatur hal-hal ini akan menjadikan manusia lebih baik. 25

Lawan dari kemaslahatan adalah kemudaratan atau kemafsadatan. Dengan demikian, jika memelihara tujuan syara'

22Abdur Rahman Dahlan, Ushul Fiqih, (Jakarta: Amzah, 2011), 310.

23Amir Syarifudin, Ushul Fiqih..., 372.

24Abdur Rahman Dahlan, Ushul Fiqih..., 311.

25Ibid. 
yang lima merupakan kemaslahatan, maka mengabaikan tujuan syara' merupakan kemudaratan. Karena kemaslahatan dan kemudaratan merupakan dua hal yang saling bertolak belakang.26

Imam Izzudin Abdus Salam seperti yang dikutip oleh Muhammad Abu Zahrah membagi lagi maslahah menjadi tiga macam, yaitu maslahah wajib, maslahah sunnah, dan maslabah mubah.27

Berdasarkan istiqra' (penelitian empiris) dan nash-nash al-Quran maupun hadis diketahui bahwa hukum syariat Islam mencakup diantaranya pertimbangan kemaslahatan manusia. Maslabah yang mu'tabarah (dapat diterima) ialah maslahah-maslahah yang bersifat hakiki, meliputi lima jaminan dasar, yaitu keyakinan agama, keselamatan jiwa, akal, keluarga dan keturunan, dan harta benda. Kelima jaminan dasar tersebut merupakan tiang penyangga kehidupan manusia agar manusia dapat hidup aman dan sejahtera.28 Para ulama pemakai maslabah dalam kajian hukum untuk persoalan-persoalan yang mursal, menetapkan empat persyaratan yang pokok sehingga kajiannya bisa diterima, yaitu:

1. Ketentuan hukumnya ditetapkan lewat penelaahan dan penelitan yang mendalam, sehingga segi-segi kemaslahatannya itu dapat diperlihatkan secara nyata tidak berupa dugaandugaan belaka. Artinya bahwa membina hukum berdasarkan kemaslahatan itu haruslah benar-benar dapat membawa kemanfaatan dan menolak kemudharatan.29

2. Tinjauan kemaslahatan tidak boleh parsial, tetapi harus lebih general dan menyeluruh, yakni tidak hanya memperhatikan kemaslahatan satu atau dua orang atau kelompok tertentu saja. Tetapi harus menyeluruh bagi umat muslim, dalam kelompok mayoritas. 30

26Ibid.

27Muhammad Abu Zahrah, Ushul Fiqih, Saefullah Ma'shum. Et. Al, Jakarta: Pustaka Firdaus, 2014), 588.

28Ibid, 451.

29Dede Rasyada, Hukum Islam dan Pranata Sosial, (Jakarta: Raja Grafindo Persada, 1996), 99.

30Ibid. 
3. Kemaslahatan itu tidak bertentangan dengan dasar-dasar yang telah ditetapkan oleh nash atau ijma'.31

4. Maslahah mursalah itu digunakan dalam kondisi yang memerlukan, yang mana seandainya masalahnya tidak diselesaikan dengan cara ini, maka seluruh umat Islam akan berada dalam kesulitan. 32

\section{Teori Gender dalam Hukum Islam}

Kata gender berasal dari bahasa Inggris yang berarti jenis kelamin. Dalam Webster's New World Dictionary, gender diartikan sebagai perbedaan yang tampak antara laki-laki dan perempuan dilihat dari segi nilai dan tingkah laku. Dalam Women's Studies Encyclopedia dijelaskan bahwa gender adalah suatu konsep kultural yang berupaya membuat pembedaan dalam hal peran, perilaku, mentalitas, dan karakteristik emosional antara laki-laki dan perempuan yang berkembang dalam masyarakat. Sedangkan Hilary M. Lips mengartikan gender sebagai harapan-harapan budaya bagi laki-laki dan perempuan (cultural expectations for women and men). Pendapat ini sejalan dengan kaum feminis, seperti Lindsey yang menganggap semua ketetapan masyarakat perihal penentuan seseorang sebagai laki-laki atau perempuan adalah termasuk bidang kajian gender (what a given society defines as masculine or feminin is a component of gender). 33

H. T. Wilson dalam Sex and Gender mengartikan gender sebagai suatu dasar untuk menentukan pengaruh faktor budaya dan kehidupan kolektif dalam membedakan laki-laki dan perempuan. Agak sejalan dengan pendapat yang dikutip Showalter yang mengartikan gender lebih dari sekedar pembedaan laki-laki dan perempuan dilihat dari konstruksi sosial budaya, tetapi menekankan gender sebagai konsep analisa yang kita dapat menggunakannya untuk menjelaskan sesuatu (gender is a analityc concept whose meanings we

31Mukhtar Yahya dan Fatkurrahman, Dasar Pembinaan Hukum Fiqih Islam, (Bandung: Al Maarif, 1997), 109.

32Amir Syarifudin, Ushul Fiqih..., 337.

33Sarifa Suhra, "Kesetaraan Gender dalam Perspektif Al Quran dan ImplikasinyaTerhadap Hukum Islam”, Jurnal Al Ulum, No. 2, Vol. 13 (Desember 2013), 376. 
work to elucidate, and a subject matter we proceed to study as we try to define it). 34

Dari berbagai definisi tersebut dapat dipahami bahwa gender adalah suatu konsep yang digunakan untuk mengetahui perbedaan laki-laki dan perempuan dilihat dari segi pengaruh sosial budaya. Gender dalam arti ini adalah suatu bentuk rekayasa masyarakat, bukannya sesuatu yang bersifat kodrati. Dalam konteks tersebut, gender harus dibedakan dari jenis kelamin (seks). Jenis kelamin merupakan pensifatan atau pembagian dua jenis kelamin manusia yang ditentukan secara biologis yang melekat pada jenis kelamin tertentu. Sedangkan konsep gender adalah suatu sifat yang melekat pada kaum laki-laki maupun perempuan yang dikonstruksi secara sosial maupun kultural, misalnya perempuan dikenal lembut dan cantik. Tidak berlebihan jika dikatakan bahwa gender adalah interpretasi budaya terhadap perbedaan jenis kelamin. Oleh karena itu, dapat dikatakan bahwa gender pada hakikatnya lebih menekankan aspek sosial, budaya, psikologis, dan aspek non biologis lainnya. Hal ini berarti gender lebih menekankan aspek maskulinitas atau feminitas seseorang dalam budaya tertentu. Dengan demikian, perbedaan gender pada dasarnya merupakan konstruksi yang dibentuk, disosialisasikan, diperkuat, bahkan dilegitimasi secara sosial dan budaya. Pada gilirannya, perbedaan gender dianggap kodrati hingga melahirkan ketidakseimbangan perlakuan jenis kelamin. 35

Dalam perkembangannya, menurut Mansour Fakih perbedaan gender akan melahirkan manifestasi ketidakadilan, antara lain terjadinya marginalisasi (pemiskinan ekonomi) terhadap kaum perempuan, terjadinya subordinasi pada salah satu jenis kelamin, pelabelan negatif (stereotip), kekerasan, menanggung beban kerja domestik lebih banyak dan lebih lama. Pada umumnya yang menjadi korban adalah perempuan dengan adanya tradisi dan keyakinan masyarakat bahwa perempuan yang bertugas dan memelihara kerapian rumah, serta tanggung jawab atas terlaksananya

34Ibid., 377.

35Ibid., 378. 
keseluruhan pekerjaan domestik.36 Nasarudin Umar mengemukakan bahwa ada beberapa variabel yang dapat digunakan sebagai standar dalam menganalisa prinsip-prinsip kesetaraan gender dalam al-Quran. Variabel-variabel tersebut antara lain sebagai berikut:

1. Laki-laki dan perempuan sama-sama sebagai hamba

Salah satu tujuan penciptaan manusia adalah untuk menyembah kepada Tuhan, sebagaimana disebutkan dalam QS. az-Zariyat: 56:

Dan aku tidak menciptakan jin dan manusia melainkan supaya mereka mengabdi kepada-Ku.37

Dalam kapasitas manusia sebagai hamba, tidak ada perbedaan antara laki-laki dan perempuan siapa yang lebih banyak amal ibadahnya, maka dialah yang mendapat pahala yang besar tanpa harus melihat dan mempertimbangkan jenis kelaminnya terlebih dahulu. Keduanya mempunyai potensi dan peluang yang sama untuk menjadi hamba ideal. Hamba ideal dalam al-Quran biasa diistilahkan dengan orang-orang yang bertakwa. Dan untuk mencapai derajat takwa ini tidak dikenal adanya perbedaan jenis kelamin, suku bangsa, atau kelompok etnis tertentu.

2. Laki-laki dan perempuan sebagai khalifah di bumi

Maksud dan tujuan penciptaan manusia di bumi adalah di samping untuk menjadi hamba yang tunduk dan patuh serta mengabdi kepada Allah, juga untuk menjadi khalifah di bumi. Kapasitas manusia sebagai khalifah di bumi ditegaskan dalam QS. al-An'am:135

Dan dialah yang menjadikan kamu penguasa-penguasa di bumi dan Dia meninggikan sebagian kamu atas sebagian (yang lain) beberapa derajat, untuk mengujimu tentang apa yang diberikan-Nya kepadamu. Sesunggubnya Tubanmu amat cepat siksaan-Nya dan sesunggubnya Dia Maha Pengampun lagi Maha Penyayang. 38

36Mansour Fakih, Analisis Gender dan Transformasi Sosial, (Yogyakarta: Pustaka Pelajar, 1996), 72-75.

37Kementerian Agama RI, Al Quran dan Terjemahnya.., 862.

38Kementerian Agama RI, Al Quran dan Terjemahnya.., 210. 
Kata khalifah dalam ayat tersebut tidak menunjuk pada salah satu kelamin atau kelompok etnis tertentu. Laki-laki dan perempuan mempunyai fungsi yang sama sebagai khalifah, yang akan mempertanggungjawabkan tugas-tugas kekhalifahannya di bumi, sebagaimana halnya mereka harus bertanggungjawab sebagai hamba Allah.

3. Laki-laki dan perempuan menerima perjanjian primordial

Laki-laki dan perempuan sama-sama mengemban amanah dan menerima perjanjian primordial dengan Tuhan. Seperti diketahui menjelang seorang anak keluar dari rahim ibunya, ia terlebih dahulu harus menerima perjanjian dengan Tuhannya sebagaimana disebutkan dalam QS al-A'raf: 172 yang artinya:

Dan (ingatlah) ketika Tubanmu mengeluarkean anak-anak. Adam dari sulbi mereka dan Allah mengambil kesaksian terbadap jiwa mereka (seraya berfirman): "bukankah Aku ini Tubanmu?" mereka menjawab: "betul (Engkau Tuhan kami), kami menjadi saksi." (Kami melakukan yang demikian itu) agar di bari kiamat kami tidak mengatakan: "seseunggubnya Kami (bani Adam) adalah orang-orang yang lengah terhadap ini (keesaan Tuban). 39

Menurut Fakhr ar-Razi tidak ada seorang pun anak manusia lahir di muka bumi ini yang tidak berikrar akan keberadaan Allah, dan ikrar mereka disaksikan oleh para malaikat. Tidak ada seorang pun yang mengatakan "tidak". Dalam Islam, tanggung jawab individual dan kemandirian berlangsung sejak dini, yaitu semenjak dalam kandungan, sejak awal sejarah manusia. Dengan demikian dalam Islam tidak dikenal adanya diskriminasi jenis kelamin. Laki-laki dan perempuan sama-sama menyatakan ikrar yang sama.

4. Adam dan Hawa terlibat secara aktif dalam drama kosmis

5. Semua ayat yang menceritakan tentang drama kosmis, yakni cerita tentang keadaan Adam dan pasangannya di surga sampai keluar ke bumi, selalu menekankan kedua belah pihak secara aktif dengan menggunakan kata ganti untuk dua orang (huma), yakni kata ganti untuk Adam dan hawa, seperti dapat dilihat dalam beberapa kasus berikut ini:

39Kementerian Agama RI, Al Quran dan Terjemahnya.., 250. 
a. Keduanya diciptakan di surga dan menikmati fasilitas surga, sebagaimana disebutkan dalam QS. al-Baqarah: 35.40

b. Keduanya mendapat godaan yang sama dari iblis, sebagaimana terdapat dalam QS. al-A'raf: 20:

c. Sama-sama memakan buah khuldi dan keduanya menerima akibat dibuang ke bumi, seperti disebutkan dalam QS. alA'raf: 22:41

d. Sama-sama memohon ampun dan sama-sama diampuni oleh Allah sebagaimana dalam QS al-A'raf: 23.42

e. Setelah di bumi keduanya mengembangkan keturunan, saling melengkapi, dan saling membutuhkan, sesuai dengan QS. al-Baqarah: 187.43

6. Laki-laki dan perempuan berpotensi meraih prestasi

Peluang untuk meraih prestasi maksimum tidak ada pembedaan antara laki-laki dan perempuan, ditegaskan secara khusus dalam beberapa ayat diantaranya QS. Ali Imran: 195:

Maka Tuban mereka memperkenankan permohonannya (dengan berfirman): "Sesunggubnya Aku tidak menyia-nyiakan amal orang- orang yang beramal di antara kamu, baik laki-laki atau perempuan, (karena) sebagian kamu adalab turunan dari sebagian yang lain. Maka orang-orang yang berbijrah, yang diusir dari kampung balamannya, yang disakiti pada jalan-Ku, yang berperang dan yang dibunuh, pastilah akan Ku-hapuskan kesalahan-kesalahan mereka dan pastilah Aku masukkan mereka ke dalam surga yang mengalir sungai-sungai di bawahnya, sebagai pabala di sisi Allah. Dan Allab pada sisi-Nya pahala yang baik.44

Ayat tersebut mengisyaratkan konsep kesetaraan gender yang ideal dan memberikan ketegasan bahwa prestasi individual, baik dalam bidang spiritual maupun urusan karier profesional, tidak mesti dimonopoli oleh salah satu jenis kelamin saja. Laki-laki dan perempuan berpeluang memperoleh

40Kementerian Agama RI, Al Quran dan Terjemahnya.., 34.

41Kementerian Agama RI, Al Quran dan Terjemahnya.., 223.

42Kementerian Agama RI, Al Quran dan Terjemahnya.., 224.

43Kementerian Agama RI, Al Quran dan Terjemahnya.., 45.

44Kementerian Agama RI, Al Quran dan Terjemahnya.., 110. 
kesempatan yang sama meraih prestasi optimal. Namun, dalam kenyataannya dalam masyarakat, konsep ideal ini membutuhkan tahapan dan sosialisasi, karena masih terdapat sejumlah kendala, terutama kendala budaya yang sulit diselesaikan.

Salah satu obsesi al-Qur'an ialah terwujudnya keadilan di dalam masyarakat. Keadilan dalam al-Qur'an mencakup segala segi kehidupan umat manusia, baik sebagai individu maupun sebagai anggota masyarakat. Karena itu al-Qur'an tidak mentolerir segala bentuk penindasan, baik berdasarkan kelompok, etnis, warna kulit, suku bangsa, dan kepercayaan, maupun yang berdasarkan jenis kelamin. Jika terdapat suatu hasil pemahaman atau penafsiran yang bersifat menindas atau menyalahi nilai-nilai luhur kemanusiaan, maka hasil pemahaman dan penafsiran tersebut terbuka untuk diperdebatkan/direinterpretasi.45

\section{PERMA Nomor 3 Tahun 2017 Tentang Pedoman Mengadili Perkara Perempuan Berhadapan Dengan Hukum}

PERMA Nomor 3 Tahun 2017 tentang Pedoman Mengadili Perkara Perempuan Berhadapan Dengan Hukum mengatur agar hakim menerapkan prinsip kesetaraan gender dan prinsip-prinsip non diskriminasi dalam mengadili suatu perkara perempuan berhadapan dengan hukum. Dalam hal ini yang harus dilakukan hakim di persidangan perkara perempuan berhadapan dengan hukum adalah sebagai berikut:

1. Dalam pemeriksaan perkara hakim diharapkan dapat mengidentifikasi fakta persidangan terkait adanya ketidaksetaraan gender dan ketidaksetaraan status sosial di masyarakat, yang mengakibatkan adanya ketimpangan gender antara perempuan dan laki-laki terutama jika perempuan menjadi korban dan/atau saksi.

2. Hakim dapat mengidentifikasi dan mempertimbangkan adanya relasi kuasa antara para pihak yang berperkara yang mangakibatkan korban/saksi tidak berdaya.

45Nasarudin Umar, Argumen Kesetaraan Gender Perspektif Al Quran (Jakarta: Paramadina, 1999), 255. 
3. Hakim dapat mengidentifikasi dan mempertimbangkan riwayat kekerasan dari pelaku terhadap korban/saksi.

4. Hakim agar mempertimbangkan dampak psikis dan fisik serta ketidakberdayaan yang dialami perempuan berhadapan dengan hukum dengan menyarankan para pihak untuk menghadirkan alat bukti lain seperti keterangan ahli dan rekam psikologis korban melalui surat keterangan psikologi, atau bila memang ada persoalan lebih serius seperti gangguan jiwa, melalui visum et repertum psychiatrium agar dapat menilai tidak hanya dampak psikis dari kekerasan tetapi juga ketidakberdayaan fisik dan psikis yang dialami perempuan berhadapan dengan hukum saat kejadian dan setelahnya.

5. Apabila perempuan korban dalam persidangan tidak mau atau tidak siap bertemu dengan pelaku maka hakim dapat memerintahkan pelaku untuk keluar dari ruang persidangan atau melakukan pemeriksaan melalui audio visual jarak jauh atau menggunakan pemeriksaan lainnya (rekaman video, dll) agar perempuan korban dapat memberikan keterangan tanpa ada tekanan dan terhindar dari trauma.

6. Selama jalannya pemeriksaan persidangan, Hakim agar mencegah dan/atau menegur para pihak, penasihat hukum, penuntut umum dan/atau kuasa hukum yang bersikap atau membuat pernyataan yang merendahkan, menyalahkan, mengintimidasi, dan/atau menggunakan pengalaman atau latar belakang perempuan berhadapan dengan hukum.

7. Hakim dapat menyarankan dan/atau mengabulkan permintaan perempuan berhadapan dengan hukum untuk menghadirkan pendamping.

8. Hakim agar mempertimbangkan kondisi ketidaksetaraan perlindungan hukum yang berdampak pada akses keadilan yang selama ini terjadi pada perempuan di masyarakat patriarki. Dengan demikian Hakim juga dapat menggunakan putusannya sebagai ruang keadilan bagi pencari keadilan, dalam hal ini bagi perempuan berhadapan dengan hukum.

Selain hal diatas terdapat juga hal yang seharusnya tidak dilakukan hakim di persidangan, yaitu sebagai berikut: 
1. Menunjukkan sikap atau mengeluarkan pernyataan yang merendahkan, menyalahkan, dan/atau mengintimidasi perempuan berhadapan dengan hukum.

2. Membenarkan terjadinya diskriminasi terhadap perempuan dengan menggunakan kebudayaan, aturan adat, dan praktik tradisional lainnya, maupun menggunakan penafsiran ahli yang bias gender.

3. Mempertanyakan dan/atau mempertimbangkan mengenai pengalaman atau latar belakang seksualitas korban sebagai dasar untuk membebaskan pelaku atau meringankan hukuman pelaku.

4. Mengeluarkan pernyataan atau pandangan yang mengandung stereotip gender.

Dengan diaturnya hal-hal diatas, diharapkan diskriminasi dan stereotip gender terhadap perempuan berhadapan dengan hukum khususnya di pengadilan dapat berkurang serta pelaksanaan pengadilan dilaksanakan secara berintegritas dan peka gender. Sehingga tidak menimbulkan dampak negatif bagi perempuan baik dampak psikis maupun fisik.46

Implikasinya kesetaran gender dan dalam hukum Islam antara lain dapat terlihat pada hal berikut:

1. Terjadinya transformasi pemikiran hukum Islam yang berkaitan dengan isu kesetaraan relasi antara laki-laki dan perempuan dalam teks al-Qur'an maupun hadis.

2. Terjadinya Transformasi pemikiran di bidang profesi seperti hakim perempuan dan profesi lainnya yang umumnya dilakukan oleh kaum laki-laki (kepemimpinan).

Masalah pengangkatan perempuan menjadi hakim, sejak dahulu telah menjadi perbincangan di kalangan ulama, ada yang membolehkan dan ada pula yang melarangnya. Dasarnya adalah hadis Rasululullah saw bersabda "Tidak akan beruntung suatu kaum apabila menyerahkan pucuk pimpinannya kepada perempuan."

46 Mahkamah Agung Republik Indonesia, Pedoman Mengadili Perkara Perempuan Berhadapan Dengan Hukum (Jakarta: Mahkamah Agung RI, 2018), 40. 
Meskipun materi hadis tersebut hanya mengenai pengangkatan pemimpin, tetapi para ulama menganalogikannya dengan pengangkatan hakim. Hal tersebut disebabkan oleh beratnya tugas seorang hakim, yang mungkin tidak jauh perbedaannya dengan seorang pemimpin negara. Hakim bertugas menyelesaikan perkara yang masuk, baik perkara itu menyangkut hak Allah swt., atau menyangkut hak sesama manusia.

Di Indonesia khususnya di pengadilan agama, memberi kesempatan kepada perempuan untuk diangkat menjadi hakim untuk memutuskan persoalan perdata tertentu yang ada kaitannya dengan hukum Islam, sehingga dapat dipastikan bahwa konsistensinya menganut paham Imam Abu Hanifah. Untuk mendukung pendapat tersebut, bahwa persoalan hukum kekeluargaan sebagai salah satu bagian dari hukum perdata Islam banyak menyangkut hal-hal yang berkaitan dengan kepribadian perempuan, dan yang paling mengetahui hal-hal tersebut adalah perempuan itu sendiri. Oleh karena itu tidak sepantasnya seorang ulama menolak pengangkatan perempuan sebagai hakim, dalam upaya membantu laki-laki menyelesaikan perkara.47

\section{Analisis Maslahah terhadap PERMA Nomor 3 Tahun 2017 Tentang Pedoman Mengadili Perkara Perempuan Berhadapan Dengan Hukum}

Tujuan Mahkamah Agung mengeluarkan peraturan ini agar para hakim dan segenap aparatur peradilan memiliki acuan dalam memahami dan menerapkan kesetaraan gender dan prinsip-prinsip non diskriminasi dalam mengadili perkara perempuan berhadapan dengan hukum. Dan juga agar melalui peraturan ini secara bertahap praktik-praktik diskriminasi berdasarkan jenis kelamin dan stereotip gender di pengadilan dapat berkurang, serta memastikan pelaksanaan pengadilan (termasuk mediasi) dilaksanakan secara berintegritas dan peka gender.

Tujuan Mahkamah Agung mengeluarkan peraturan ini sejalan dengan QS. Al-Hujurat: 13

47Ibid, 129-130. 
Hai manusia sesunggubnya kami menciptakan kamu dari seorang laki-laki dan seorang perempuan dan menjadikan kamu berbangsabangsa dan bersuku-suku supaya kamu saling mengenal. Seseunggubnya orang yang paling mulia diantara kamu adalab orang yang paling bertakwa diantara kamu. 48

Ayat tersebut memberikan gambaran tentang persamaan antara laki-laki dan perempuan baik dalam hal ibadah (dimensi spiritual) maupun dalam aktivitas sosial (urusan karier profesional). Ayat tersebut juga sekaligus mengikis tuntas pandangan yang menyatakan bahwa antara keduanya terdapat perbedaan yang memarginalkan salah satu diantara keduanya, persamaan tersebut meliputi berbagai hal misalnya dalam bidang ibadah. Siapa yang rajin ibadah, maka akan mendapat pahala lebih banyak tanpa melihat jenis kelaminnya. Perbedaan kemudian ada disebabkan kualitas nilai pengabdian dan ketakwaannya kepada Allah swt.

Perbedaan gender sesungguhnya tidak menjadi masalah sepanjang tidak melahirkan ketidakadilan gender. Ketidakadilan gender ini merupakan bentuk perbedaan perlakuan berdasarkan alasan gender, seperti pembatasan peran, pemikiran, atau perbedaan perlakuan yang mengakibatkan terjadinya pelanggaran atas pengakuan hak asasi, persamaan hak antara laki-laki dan perempuan. Diantara bentuk-bentuk ketidakadilan gender disini yaitu:

1. Subordinasi adalah kondisi dimana perempuan ditempatkan pada posisi subordinat (lebih rendah) dari laki-laki yang terjadi di ruang privat ataupun publik. Contohnya didalam sebuah keluarga biasanya perempuan tidak mendapat kesempatan untuk turut mengambil keputusan atau mengeluarkan pendapat.

2. Stereotip Gender adalah pelabelan atau penandaan terhadap suatu kelompok tertentu yang seringkali merugikan dan menimbulkan ketidakadilan. Misalnya, stereotip yang berawal dari asumsi bahwa perempuan berdandan untuk menarik perhatian lawan jenis, maka setiap ada kasus kekerasan atau pelecehan seksual selalu dikaitkan dengan stereotip tersebut sehingga menimbulkan anggapan negatif bahwa yang menjadi

48Kementrian Agama RI, Al Quran dan Tafsirnya,(Jakarta: Widya Cahaya, 2011), 516. 
penyebab perempuan dilecehkan secara seksual adalah akibat kesaahan perempuan itu sendiri. Masyarakat lalu mencari-cari kesalahan korban dan cenderung memaklumi tindakan pelaku.

3. Beban ganda artinya beban pekerjaan yang diterima salah satu jenis kelamin lebih banyak dibandingkan jenis kelamin lainnya. Disatu sisi perempuan direndahkan dan dianggap kurang penting, di sisi lain sesungguhnya dalam realitas hidup perempuan memiliki banyak peran dan pekerjaan. Perempuan memiliki peran domestik dan reproduksi, kerja produktif, dan juga kerja sosial. Perempuan memiliki beban kerja majemuk tetapi sering pekerjaannya tidak disadari, tidak dihargai, atau tidak dianggap sebagai bentuk pekerjaan karena tidak langsung menghasilkan nilai tukar uang.

4. Marginalisasi adalah suatu proses peminggiran dari akses sumber daya atau pemiskinan yang dialami perempuan akibat konstruksi gender di masyarakat. Contohnya, karena perempuan dianggap sebagai makhluk domestik/reproduksi lebih diarahkan sebagai pengurus rumah tangga. Sementara karena laki-laki dianggap sebagai pencari nafkah atau memiliki peran publik/produktif menyebabkan laki-laki lebih memiliki posisi yang superior dibanding perempuan.

5. Kekerasan, dari semua sumber kekerasan yang ada, salah satu kekerasan terhadap jenis kelamin tertentu, yakni perempuan disebabkan oleh anggapan gender yang eksis di masyarakat patriarki, misalnya adanya anggapan bahwa perempuan itu lemah, pasrah, dan menjadi objek seksual. Sehingga menempatkan perempuan sebagai objek yang mudah diserang. Kekerasan yang disebabkan oleh eksisnya anggapan gender ini disebut sebagai kekerasan berbasis gender. Kekerasan berbasis gender terhadap perempuan disebut juga kekerasan terhadap perempuan.

Kelima bentuk ketidakadilan gender diatas merupakan bagian diskriminasi terhadap perempuan. Dengan usaha Mahkamah Agung dalam pemberantasan diskriminasi dan stereotip gender terhadap perempuan berhadapan dengan Hukum dibentuklah peraturan ini.

Menurut Al Syatibi ada tiga kategori tingkatan kebutuhan untuk mencapai kemaslahatan, yaitu pertama dharuriyah, bajizyah, dan 
tahsiniyah. Berdasarkan hal diatas dibentuknya peraturan ini termasuk maslahabh ajiyah, yakni termasuk dalam kebutuhan sekunder, dimana tidak terwujudkannya kebutuhan ini tidak sampai mengancam keselamatannya, namun akan mengalami kesulitan yang mungkin bahkan berkepanjangan, tetapi tidak sampai ke tingkat menyebabkan kepunahan atau sama sekali tidak berdaya. Kemaslahatan ini dibutuhkan manusia, khususnya perempuan berhadapan dengan hukum untuk kemudahan hidupnya dan menghilangkan kesulitan baginya.

Dengan adanya peraturan ini diharapkan segala bentuk diskriminasi terhadap perempuan berkurang dan bahkan hilang sama sekali. Sehingga perempuan berhadapan dengan hukum dapat mendapatkan haknya dengan layak dan dapat melanjutkan hidupnya dengan baik. Dan juga dengan dikeluarkannya PERMA ini diharapkan tidak lagi terjadi stereotip gender dalam pemeriksaan di pengadilan yang dapat berdampak negatif terhadap perempuan berhadapan dengan hukum baik berupa dampak psikis maupun fisik. Serta munculnya putusan yang bias gender.

\section{Penutup}

Latar belakang dibentuknya PERMA Nomor 3 Tahun 2017 Tentang Pedoman Mengadili Perkara Perempuan Berhadapan Dengan Hukum adalah karena perempuan seringkali menghadapi rintangan berganda dalam meraih pemenuhan haknya yang disebabkan oleh diskriminasi dan pandangan stereotip negatif berdasarkan jenis kelamin dan gender. Perlakuan diskriminatif dan stereotip gender terhadap perempuan dalam sistem peradilan berbanding lurus dengan aksesibilitas perempuan untuk mendapatkan keadilan. Semakin perempuan mengalami diskriminasi dan/atau stereotip negatif maka akan semakin terbatas akses perempuan terhadap keadilan. Melihat kondisi tersebut, Mahkamah Agung sebagai lembaga pengadilan tertinggi berinisiatif untuk mengambil langkah guna secara bertahap memastikan tidak adanya diskriminasi berdasarkan gender dalam praktik peradilan di Indonesia. Salah satu langkah kongkrit Mahkamah Agung adalah dengan mengeluarkan Peraturan Mahkamah Agung Republik Indonesia Nomor 3 Tahun 2017 Tentang Pedoman Mengadili Perkara PerempuanBerhadapan Dengan Hukum. 
Dikeluarkannya PERMA nomor 3 tahun 2017 ini merupakan maslahah hajiyah karena kemaslahatan ini yang dibutuhkan manusia, khususnya perempuan berhadapan dengan hukum untuk kemudahan hidupnya dan menghilangkan kesempitan. Apabila tidak ada, maka tidak sampai menyebabkan rusaknya tatanan kehidupan, seperti dalam maslahah daruri, tetapi akan menimbulkan kesempitan dan kesulitan.Memberi kemudahan hidup dan meghilangkan kesempitan disini adalah dengan dikeluarkannya PERMA ini diharapkan tidak lagi terjadi stereotip gender dalam pemeriksaan di pengadilan yang dapat berdampak negatif terhadap perempuan berhadapan dengan hukum baik berupa dampak psikis maupun fisik. Serta munculnya putusan yang bias gender.

Dengan dikeluarkannya PERMA Nomor 3 Tahun 2017 tentang Pedoman Mengadili Perkara Perempuan Berhadapan Dengan Hukum agar para hakim dan segenap aparatur peradilan dalam menangani perkara yang melibatkan perempuan baik sebagai pelaku, korban, saksi, dan para pihak dapat menjadi standar dalam proses pemeriksaan di pengadilan. Sehingga tujuan penghapusan segala potensi diskriminasi terhadap perempuan yang berhadapan dengan hukum dapat tercapai.

\section{Daftar Pustaka}

Aminah, Siti "Dekonstruksi Fikih Maskulin: Studi Kritis atas Kasus Amina Wadud sebagai Imam Shalat Jum'at di Gereja Italian Unity, Morgantown, West Virginia, Amerika Serikat". Skripsi- - UIN Sunan Ampel, Surabaya, 2006.

Anik Mahmudah, "Produktifitas Perempuan: Studi Analisis Produktifitas Perempuan dalam Konsep Islam”. Tesis- UIN Sunan Ampel, Surabaya, 2004.

Arijaya, Rahmat. "Inilah Materi Pelatihan Perma Nomor 3 Tahun 2017”,

dalamhttps://badilag.mahkamahagung.go.id/seputarditjen-badilag/ seputar-ditjen-badilag/inilah-materipelatihan-perma-nomor-3-tahun-2017, diakses pada 18 november 2017.

Az Zuhaili, Wahbah. UshulFiqih Al Islami, Juz II, Beirut: Darul Fikri, 1986. Nasution, Haroen. Ushul Fiqih, Jilid I, Jakarta: Logos Wacana Ilmu, 1997. 
Choiri, A. "Berkah PERMA Nomor 3 Tahun 2017 bagi Kaum Perempuan dan Anak Sebagai Korban Perceraian", dalam http://berkah-perma-nomor-3-tahun-2017-bagi-kaumperempuan-dan-anak-sebagai-korban-perceraian/.pdf, diakses pada 18 November 2017.

Dahlan, Abdur Rahman Ushul Fiqih, Jakarta: Amzah, 2011.

Fakih, Mansour. Analisis Gender dan Transformasi Sosial, Yogyakarta: Pustaka Pelajar, 1996.

Hakim, Abdul Hamid. Al-Bayyan, Juz III, Jakarta: Syaadah Putra, tt. Hamka, Tafsir Al Az̧har, Juz XI, Jakarta: Pustaka Panji Mas, 1984.

Haroen, Nasrun. Ushul Fiqih, Jilid II, Jakarta: Logos Wacana Ilmu, 1997.

K Halimatus Sya'dia, “Analisis Maslahah Mursalah Terhadap Praktek Peraturan Menteri Agama Nomor 11 Tahun 2007 tentang Perbaikan dan Perubahan dalam Biodata Akta Nikah (Kajian Penetapan No. 1035/Pdt.P/PA.Kab.Malang)". Skripsi - - UIN Sunan Ampel, Surabaya, 2016.

Khalaf, Abdul Wahab. Mashadir al-tasri' al-islam, ttp, Dar al Qalam, 1978.

Kusdarini, Eny. "Keadilan dan Kesetaraan Gender", dalamhttp://staff.uny.ac.id/sites/default/files/pengabdian Leny-kusdarini-shmhum/ppm-keadilan-dan-kesetaraangender.pdf, diakses pada tanggal 3 Januari 2018.

Mufidah CH, "Kesetaraan dan Keadilan Gender di Pondok Pesantren Salafiyah Syafi'iyah Sukorejo Situbondo Jawa Timur". Disertasi - - UIN Sunan Ampel, Surabaya, 2009.

Muhammad, Husein. Fiqih Perempuan: Refleksi Kiai atas Wacana Agama dan Gender. Yogyakarta: LkiS, 2009.

Munawir, A. Warson. Kamus Al Munawir, Surabaya: Pustaka Progresif, 1997.

Nasarudin Umar, Argumen Kesetaraan Gender Perspektif Al Quran. Jakarta: Paramadina, 1999.

Pokja Perempuan dan Anak Mahkamah Agung Republik Indonesiadan MaPPI FHUI, Pedoman Mengadili Perkara Perempuan Berhadapan Dengan Hukum, Jakarta: AIPJ 2018. 
Qorib, Fathan. "4 Larangan Hakim saat Mengadili Perkara Perempuan", dalamhttp://www.hukumonline.com/berita/baca/lt98bdd cec400/4-larangan-hakim-saat-mengadili-perkaraperempuan/, diakses pada 18 November 2017.

Rasyada, Dede. Hukum Islam dan Pranata Sosial, Jakarta: Raja Grafindo Persada, 1996.

Sahbani, Agus. "Penting!!! Urgensi terbitnya PERMA Pedoman Mengadili Perkara Perempuan, dalam http://www.hukumonline.com /berita/baca/lt598af94b94acd/penting-urgensi-terbitnyaperma-pedoman-mengadili-perkara-perempuan,_diakses pada 18 November 2017.

Suhra, Sarifa "Kesetaraan Gender Dan Implikasinya Dalam Hukum Islam”, Jurnal al-Ulum, No. 2 Vol. 13, Desember 2013.

Sujarweni, Wiratna. Metodologi Penelitian, Yogyakarta: Pustaka Baru Press, 2014.

Supriyadi, "Perma tentang Pedoman Mengadil Perkara Perempuan dinilai Sebagai Terobosan Hukum, dalamhttp://wartakota.tribunnews.com/2017/08/13/per ma-tentang-pedoman-mengadili-perkara-perempuandinilai-sebagai-terobosan-hukum?page $=$ all diakses pada 18 November 2017.

Syafei, Rachmat. Imu Ushul Fiqih, Bandung: Pustaka Setia, 1998.

Syarifudin, Amir. Ushul Fiqib, Jilid 2, Jakarta: Kencana, 2008.

Umar Shihab, Hukum Islam dan Transformasi Pemikiran, Semarang: Dina Utama, 1996.

Yahya, Mukhtar dan Fatkurrahman, Dasar Pembinaan Hukum Fiqib Islam, Bandung: Al Maarif, 1997.

Zahrah, Muhammad Abu. Ushul Fiqih, Saefullah Ma'shum. Et. Al. Jakarta: Pustaka Firdaus, 2014.

Zuhdi, Masfuk. Pengantar Hukum Syariat, Jakarta: Haji Mas Agung, 1990. 